\title{
Storability, Quality Changes, and General Postharvest Behavior of Dudaim Melon Harvested at Two Maturity Stages
}

\author{
Mohsen Hatami ${ }^{1}$, Siamak Kalantari ${ }^{1,3}$, Forouzandeh Soltani ${ }^{1}$, and \\ John C. Beaulieu ${ }^{2}$
}

\begin{abstract}
AdDitional INDEX wORDs. Cucumis melo, anthesis, storage, sugar, ethylene
Summary. Dudaim melon (Cucumis melo Group Dudaim) is a unique edible melon for which few postharvest physiology studies have been conducted. To investigate the postharvest behavior of dudaim melon, two cultivars (Zangi-Abad and Kermanshah) were planted, tagged at anthesis, and harvested at two maturity stages: 21 and $28 \mathrm{~d}$ after anthesis (DAA). Harvested fruit were stored at 5 or $13{ }^{\circ} \mathrm{C}$ for up to 3 weeks and various quality parameters including color, firmness, titratable acidity (TA), total soluble solids (TSS), weight loss, chilling injury (CI), ethylene production, protein content, glucose content, fructose content, sucrose content, and maltose content were assessed during storage. After 3 weeks of storage at $13{ }^{\circ} \mathrm{C}$, early-harvested fruit $(21 \mathrm{DAA})$ had relatively similar color values $\left(L^{*}\right.$, lightness; $a^{*}$, green-red tones; $b^{*}$, blue-yellow tones) and TA compared with lateharvested fruit (28 DAA); however, some quality traits, such as TSS, were not similar. Ethylene content decreased initially after harvest and then started to increase during storage at $13^{\circ} \mathrm{C}$. For most treatments, glucose and fructose contents decreased whereas sucrose and maltose contents increased with advancing maturity. Increased ethylene production, in concert with color development at $13{ }^{\circ} \mathrm{C}$, similar to ripe fruit, and the changing balance of measured mono- and disaccharide sugars in harvested fruit likely indicates 'Kermanshah' is climacteric. Results for 'ZangiAbad' were not as definitive. Dudaim melon fruit can be harvested at an optimum stage of maturity, similar to known climacteric melon fruit, and then allowed to ripen at proper storage temperatures before consumption. Based on the results of this study, we recommend that harvest at $21 \mathrm{DAA}$ and storage at a nonchilling temperature such as $13{ }^{\circ} \mathrm{C}$ are the optimal stage and temperature for long storage purposes.
\end{abstract}

$M$ elon (Cucumis melo) is one of the most important horticultural crops in Iran. Worldwide, more than 31 million $t$ of melons were produced in 2016, with China, Turkey, and Iran being the major producers (Food and Agriculture Organization of the United

Received for publication 25 Apr. 2018. Accepted for publication 19 Feb. 2019.

Published online 20 May 2019.

The financial support provided by the University of Tehran is gratefully acknowledged.

We thank Ms. Panam, Ms. Rashidi, Ms. Saeidi, and Mr. Mousavi for assisting with the field and laboratory experiments.

${ }^{1}$ Department of Horticultural Sciences, College of Agriculture and Natural Resources, University of Tehran, Karaj, Iran

${ }^{2}$ U.S. Department of Agriculture, Agricultural Research Service, Southern, Regional Research Center, 1100 Robert E. Lee Boulevard, New Orleans, LA 70124

${ }^{3}$ Corresponding author. E-mail: kalantaris@ut. ac.ir.

This is an open access article distributed under the CC BY-NC-ND license (https://creativecommons.org/ licenses/by-nc-nd/4.0/).

https://doi.org/10.21273/HORTTECH04057-18
Nations, 2016). The dudaim or queen anne's pocket melon is a special melon traditionally cultivated in Iran. It is characterized by small reddish yellow fruit with ochre stripes, and a round or slightly oval shape with velvety skin. It has a uniquely fragrant and musky aroma (Aubert and Pitrat, 2006; Shu et al., 1995), and a whitish and insipid pulp that is barely edible (Raghami et al., 2013). The fragrance of the melon has been generally described as a mix of cantaloupe, pineapple, and a hint of jasmine (Aubert and Pitrat, 2006). Dudaim melons are not sweet, but are valued for their high fragrance, ornamental beauty, and medicinal properties (Soltani et al., 2010). In Kermanshah province, one of the important places of melon production in Iran, Iranian farmers grew almost 689 ha of dudaim melon, with a total production of 12,000 $\mathrm{t}$ (Islamic Republic News Agency, 2014).

There are 19 horticultural groups of melon, with dudaim being one of them (Pitrat, 2016). As a result of known and probable interbreeding among melons and melon types, the dudaim and chito $(C$. melo Group Chito) groups were combined because some melons typically termed dudaim did not always have white flesh or lacked sweetness (Munger and Robinson, 1991). The fruit mature $\approx 1$ month after pollination and detach from the plant when ripe (Hatami et al., 2016). The stripes change color as the fruit approaches maturity. The dark-green stripes become intense orange, maroon, or brown and the light-green stripes become intense yellow (Paris et al., 2012).

We have demonstrated previously that the best apparent ripening indices for dudaim melons are the color change of stripes and tendril condition (yellow or dry tendril), and the recommended internal ripening indices are color of fruit flesh and TSS content (Hatami et al., 2016). However, there is often noted variability between and within melon types regarding ethylene production, softening, and postharvest chilling sensitivity (Fernandez-Trujillo et al., 2008; Pech et al., 2008).

Melon fruit ripening is a genetically determined event that involves a series of changes in color, texture, firmness, aroma, and flavor, making

\begin{tabular}{llll}
\hline $\begin{array}{l}\text { Units } \\
\text { To convert U.S. to SI, } \\
\text { multiply by }\end{array}$ & U.S. unit & SI unit & $\begin{array}{l}\text { To convert SI to U.S., } \\
\text { multiply by }\end{array}$ \\
\hline 29,574 & $\mathrm{fl} \mathrm{oz}$ & $\mu \mathrm{L}$ & $3.3814 \times 10^{-5}$ \\
29.5735 & $\mathrm{fl} \mathrm{oz}$ & $\mathrm{mL}$ & 0.0338 \\
0.3048 & $\mathrm{ft}$ & $\mathrm{m}$ & 3.2808 \\
25.4 & inch $(\mathrm{es})$ & $\mathrm{mm}$ & 0.0394 \\
4.4482 & lbf & $\mathrm{N}$ & 0.2248 \\
1 & $\mathrm{micron}(\mathrm{s})$ & $\mu \mathrm{m}$ & 1 \\
28.3495 & $\mathrm{oz}$ & $\mathrm{g}$ & 0.0353 \\
0.001 & $\mathrm{ppm}$ & $\mathrm{mg} \cdot \mathrm{mL}^{-1}$ & 1000 \\
1 & $\mathrm{ppm}$ & $\mu \mathrm{L} \cdot \mathrm{kg}^{-1}$ & 1 \\
$\left({ }^{\circ} \mathrm{F}-32\right) \div 1.8$ & ${ }^{\circ} \mathrm{F}$ & ${ }^{\circ} \mathrm{C}$ & $\left({ }^{\circ} \mathrm{C} \times 1.8\right)+32$ \\
& & &
\end{tabular}


fruit scent and flavor appealing to consumers (Nunez-Palenius et al., 2008). Decreasing growth rate and increasing soluble solids contents are important physiologic changes that clearly precede accelerated ethylene production. Because melons do not store starch, ethylene cannot affect soluble solids content by increasing starch hydrolysis, as in banana (Musa acuminata) or pear (Pyrus communis) (Pratt, 1971; Pratt et al., 1977). The flavor of fruit and vegetables and their quality depend mainly on the amount of soluble sugars such as glucose, fructose, maltose, and sucrose (Cai et al., 2015). Sugar content (related to sweetness), volatile content (related to flavor and aroma), and the texture of melon fruit are important indices of maturity (Beaulieu, 2006; Beaulieu and Lancaster, 2007).

The ripening process in melons includes both ethylene-dependent and ethylene-independent pathways (Pech et al., 2008). Some ripeningassociated events, such as degreening of the rind and cell separation in the peduncular abscission zone, are totally dependent on ethylene. In contrast, some other ripening events, such as softening and membrane deterioration, depend only partially on ethylene and display some ethyleneindependent components (Flores et al., 2001).

To the best of our knowledge, there are no publications that elucidate the climacteric ethylene production in dudaim fruit. Although the postharvest attributes in other groups of melon such as inodorus (C. melo Group Inodorus) and cantalupensis (C. melo Group Cantalupensis) have been investigated extensively, the dudaim group is limited to the studies of Aubert and Pitrat (2006), Shu et al. (1995), and Zeinalipour et al. (2017). The goal of this work was to evaluate the storability, quality changes, and general postharvest behavior of different maturity stages in dudaim melon during storage.

\section{Material and methods}

Planting and harvesting. Two cultivars of dudaim melon (Zangi-Abad and Kermanshah) were direct-seeded in a randomized complete block design at the MohammadShahr Research Station (Karaj, Iran) of the Horticultural Science Department of the University of Tehran. There were three rows per cultivar, six plants per row in the field, totaling 18 plants per treatment. The spacing was $1 \mathrm{~m}$ between rows and $0.5 \mathrm{~m}$ between plants in rows. Watering was accomplished by the drip tape method every $3 \mathrm{~d}$, and the average diurnal temperature was $27.9^{\circ} \mathrm{C}$ (average maximum temperature, $35.9{ }^{\circ} \mathrm{C}$; average minimum temperature, 19.9 $\left.{ }^{\circ} \mathrm{C}\right)$. The soil type was a clay loam (46.2\% clay, $31.2 \%$ silt, $22.6 \%$ sand) without fertilizer application and no chemical pest control.

About $30 \mathrm{~d}$ after seed germination, female flowers were tagged on the day of anthesis and fruit were harvested at two maturity stages: 21 and 28 DAA. These harvest stages were determined from other field trials in which fruit generally had a green rind color at about 21 DAA (early harvest), which became an orange, mottled fully ripe color (light-yellow background) by about $28 \mathrm{DAA}$ (late harvest) and, if left in the field, would display the maroon/brown-mottled color (orange background) by about 35 DAA (Hatami et al., 2016). Harvested fruit were stored at 5 or $13{ }^{\circ} \mathrm{C}$ for 3 weeks (relative humidity, $90 \%$ to $95 \%$ ) to investigate possible alterations in ethylene production and chilling sensitivity. Quality parameters were measured every 7 $\mathrm{d}$ in storage. Storage at ambient room temperature was the standard for progressive stages of fruit color change, as shown in Fig. 1.

QuALITY ANALYSES. Surface color values including $L^{*}, a^{*}$, and $b^{*}$ were measured using a colorimeter (Chroma Meter model CR-400; Minolta, Osaka, Japan) at three random points on the fruit rind (within the dark-strip areas; the ground color was not measured). Fruit firmness was measured at two points on the equatorial zone of the fruit, without pre-peeling the epidermis, using a hand-held firmness penetrometer (FT 327; Effegi, Alfonsine, Italy) fitted with an 8-mm-diameter plunger tip. Fruit were measured at storage temperatures and the mean skin thickness for the two cultivars was about $1 \mathrm{~mm}$. Titratable acidity was expressed as a percentage of citric acid, as measured by titrating $5 \mathrm{~mL}$ fruit juice with $0.01 \mathrm{~N}$ sodium hydroxide to a $\mathrm{pH}$ endpoint of 8.1. Soluble solids content of the fruit juice was determined using a hand-held refractometer (Nl; Atago, Bellevue, WA). Weight loss was expressed as the percentage loss of the initial total fruit weight. Fruit decay was evaluated only as a symptom of CI.

Sugar anAlysis. To measure glucose, fructose, sucrose, and maltose, $1 \mathrm{~mL}$ fruit juice was extracted from $30 \mathrm{~g}$ mesocarp tissue using a garlic press from both fruit within the replicate. Juices were centrifuged at $10,000 \mathrm{~g}_{\mathrm{n}}$ and then the supernatants were filtered through a $0.2-\mu \mathrm{m}$ syringe filter. Thereafter, $10 \mu \mathrm{L}$ was injected into an ultra-high-performance liquid chromatography (PLATINblue; Knauer, Berlin, Germany) equipped with an amide $\left(\mathrm{NH}_{2}\right)$ column $[250 \times$ $4.6 \mathrm{~mm}$ i.d. (Asahipak NH2p-50; Shodex, Tokyo, Japan)] and a smart refractive index detector. A mixture of $75 \%$ acetonitrile with 25\% ultrapure water $(\mathrm{v} / \mathrm{v})$ was used as the mobile phase, and the flow rate was set at 1 $\mathrm{mL} \cdot \mathrm{min}^{-1}$. Glucose, fructose, sucrose, and maltose were identified and quantified using sugar standards, and results are expressed as milligrams per milliliter (Muir et al., 2009).

ETHYLENE PRODUCTION. Ethylene production was determined according to Hatami et al. (2016) for individual fruit within the replicate during storage at their respective temperatures; results are reported as microliters per kilogram per hour. Fruit were placed into individual jars that were quickly purged of air and sealed. The jars were held closed (static) for $1 \mathrm{~h}$ at 5 or $13{ }^{\circ} \mathrm{C}$. The fruit held under the static conditions accumulated ethylene gas at the respective holding temperatures, per treatment design, then the ethylene concentration inside the jars was measured by taking a $1-\mathrm{mL}$ gas sample from the headspace. Samples were injected into a gas chromatograph (7890A; Agilent Technologies, Santa Clara, CA) using a capillary column $[100 \mathrm{~m} \times 0.25 \mathrm{~mm} \times 0.2 \mu \mathrm{m}$ (CP-Sil 88; Varian, Palo Alto, CA)] equipped with a flame ionization detector.

CI ASSESSMEnt. Chilling injury was assessed visually after $21 \mathrm{~d}$ of storage plus $2 \mathrm{~d}$ at room temperature using two fruit per replicate $(2$ cultivars $\times 2$ maturity stages $\times 2$ storage temperatures $\times 3$ replications $\times 2$ observations $=48$ fruit). Symptoms evaluated included skin lesions, severity of irregular coloring, pitting, cracking, and decay. The visual assessment was performed using a 0 - to 3 -point scale where $0=$ no injury (no signs), $\mathrm{l}=$ slight injury $(<20 \%$ of surface area), 

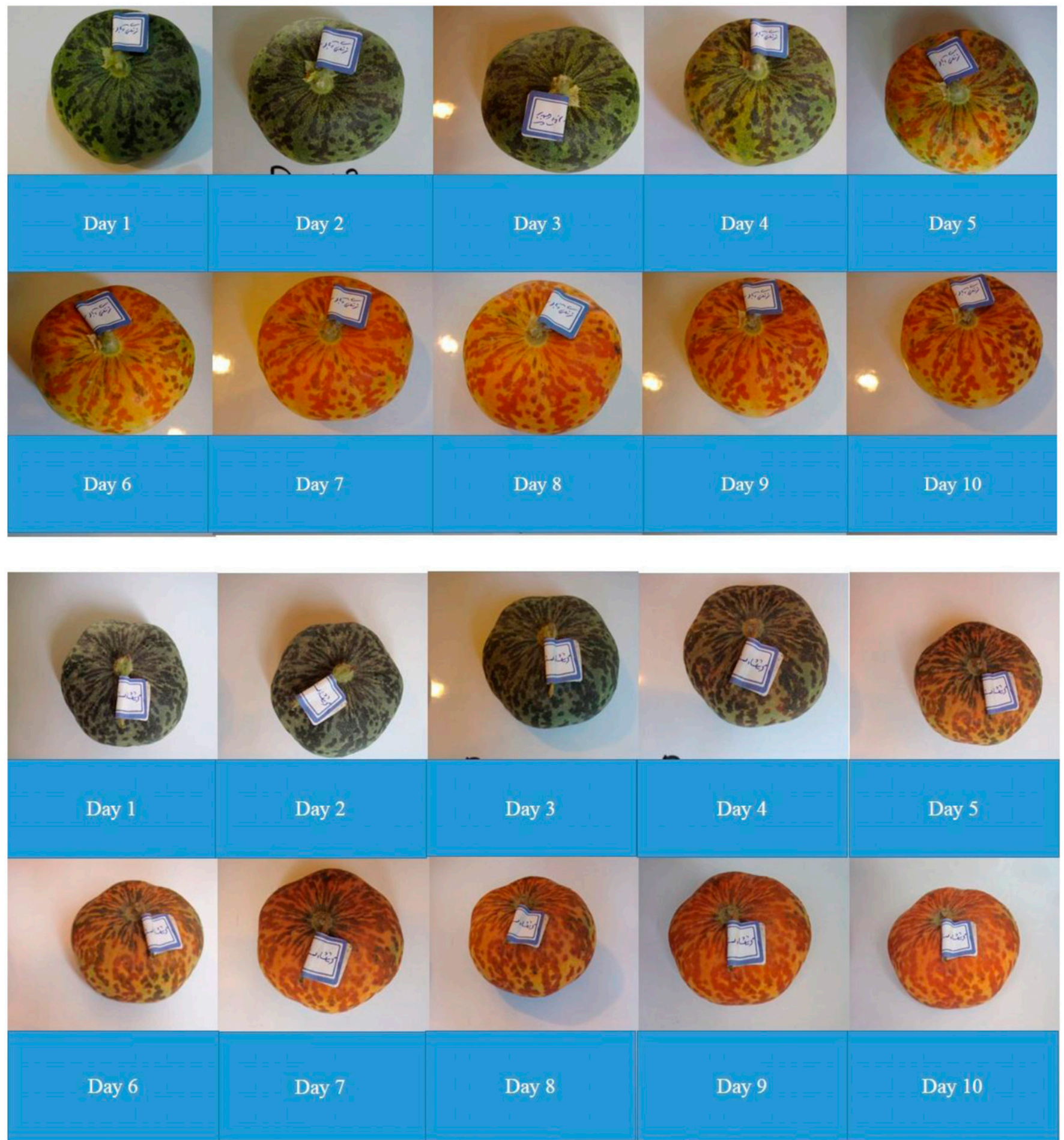

Fig. 1. Early-harvested (21 d after anthesis) 'Zangi-Abad' (top) and 'Kermanshah' (bottom) dudaim melon fruit held at room temperature for $10 \mathrm{~d}$.

$2=$ moderate injury $(20 \%$ to $50 \%$ of surface area), and $3=$ severe injury ( $>50 \%$ of surface area). Chilling injury was calculated as

$$
\mathrm{CI}=\frac{\sum(\text { Scale } \times \mathrm{N})}{\text { Total fruit no. }}
$$

where $\mathrm{N}$ is the number of fruit on the corresponding scale (Lu et al., 2010).
Protein content. Estimation of protein concentration was determined using the method of Bradford (1976), with bovine serum albumin as the standard. The amount of protein in chromatographic fractions was measured by absorbance on a spectrophotometer at $595 \mathrm{~nm}$ (S2100UV; Unico, Princeton, NJ).
Statistical analysis. The experiment was performed according to a factorial design with cultivar (Zangi-Abad and Kermanshah), maturity stage (2l and $28 \mathrm{DAA}$ ), storage temperature $\left(5\right.$ and $\left.13{ }^{\circ} \mathrm{C}\right)$, and sampling time $(0,7,14$, and $21 \mathrm{~d})$ as the main factors with three replicates and two fruit per replicate $(2 \times 2 \times 2 \times 4 \times$ 
$3 \times 2=192$ fruit as experimental units), based on a completely randomized design. Data were subjected to an analysis of variance using SAS software (version 9.1; SAS Institute, Cary, NC). When significant difference were detected $(P<0.01)$, Duncan's new multiple range test was used to compare the mean of treatments.

\section{Results and discussion Color}

In general, fruit harvested at 21 DAA had a green color and fruit harvested at 28 DAA had an orange color (Figs. 1-3). The 28 DAA $a^{*}$ values were significantly greater compared with the earlier harvested (21 DAA) fruit. The $a^{*}$ value is a good indicator of red color development and the degree of ripening in melon. Overall, the $a^{*}$ color change displayed greater values in fruit harvested at 28 DAA than those harvested earlier at 21 DAA (Fig. 4). This clearly indicates the color changed with advancing maturity, as positive $a^{*}$ values indicate the orange-red of ripe fruit, whereas negative readings (lower values) indicate the greenness of earlier harvested fruit. The $a^{*}$ values of fruit from the 28-DAA harvest did not change significantly during 3 weeks of storage at either storage temperature (Fig. 4). Fruit from the earlier 21-DAA harvest that were stored at $5{ }^{\circ} \mathrm{C}$ did not attain similar $a^{*}$ values compared with those stored at $13{ }^{\circ} \mathrm{C}$ and all fruit harvested at 28 DAA (Fig. 3). Color changes in 'Kermanshah' fruit were similar to 'Zangi-Abad' fruit, except that earlyharvested fruit stored at $13{ }^{\circ} \mathrm{C}-$ although exhibiting a noticeable increase in $a^{*}$ values-did not quite attain $a^{*}$ levels as high as lateharvested fruit (Fig. 4).

At the beginning of storage, $b^{*}$ values of late-harvested fruit were significantly greater than those of early-harvested fruit of both cultivars (Fig. 4). At $13{ }^{\circ} \mathrm{C}$, the $b^{*}$ value of early harvested fruit increased sharply until the end of the storage, when early-harvested 'Zangi-Abad' fruit attained greater $b^{*}$ values compared to late-harvested fruit. The profile of $b^{*}$ color changes for lateharvested fruit (28 DAA) at both storage temperatures and early 21 DAA-harvested fruit at $5{ }^{\circ} \mathrm{C}$ was constant and there were no significant
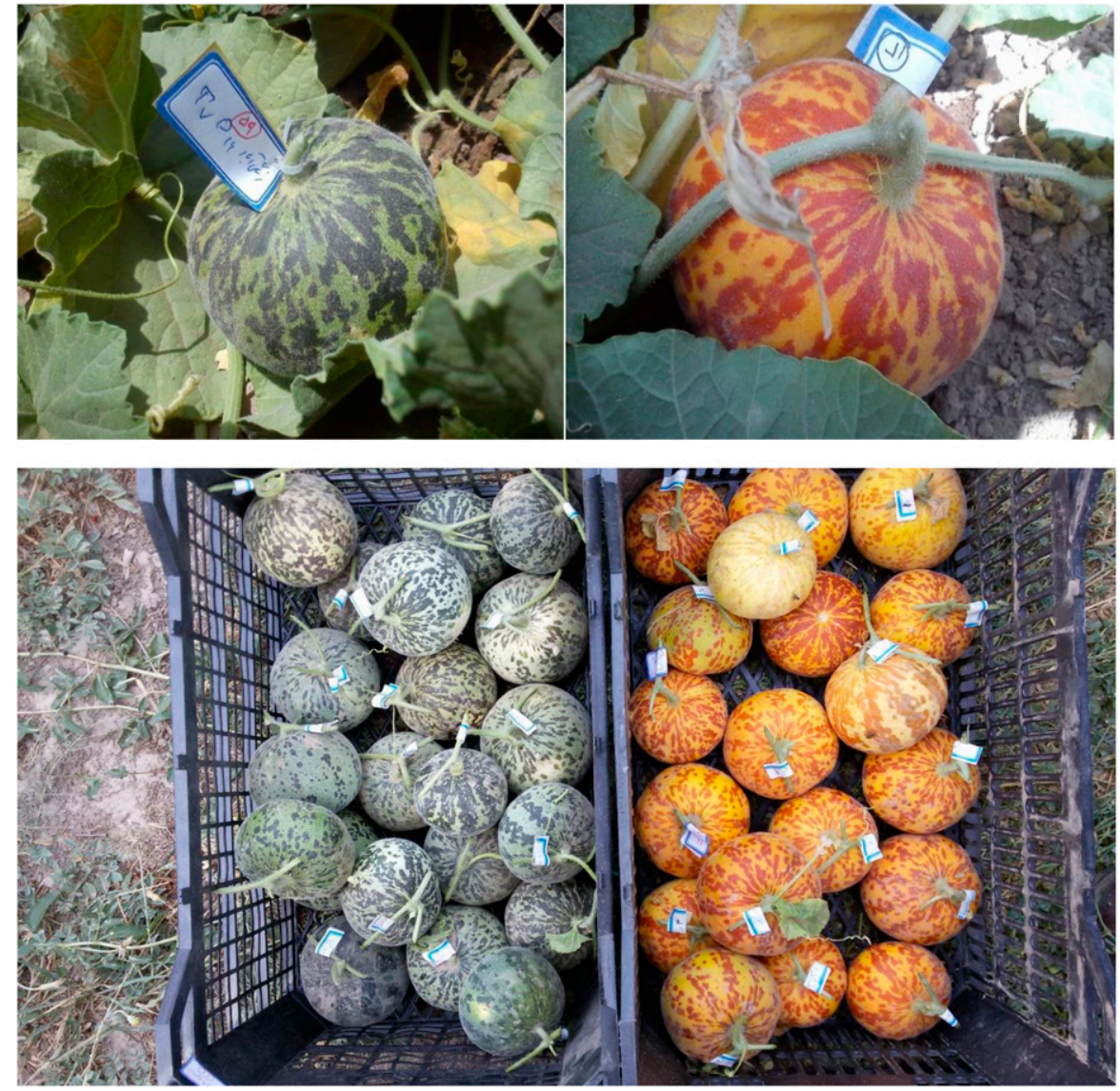

Fig. 2. Early-harvested [ $21 \mathrm{~d}$ after anthesis (left fruit)] and late-harvested [28 d after anthesis (right fruit)] 'Zangi-Abad' (top) and 'Kermanshah' (bottom) dudaim melon fruit.

changes during storage. Concomitant with the ripening of dudaim fruit, there was a color change toward yellow (positive $b^{*}$ value). Silva et al., (2004) also reported increasing $b^{*}$ color in cantaloupe (C. melo Group Cantalupensis) rind with the progression of maturation.

Contrary to the results of earlyharvested fruit at $5{ }^{\circ} \mathrm{C}$, those stored at $13{ }^{\circ} \mathrm{C}$ had similar $L^{*}$ values as lateharvested fruit until the end of the storage. In general, the stripes changed color upon approaching maturity; the dark green became intense orange or maroon or brownish and the light green became intense yellow. In other words, $a^{*}$ and $b^{*}$ tended toward positive values (more yellow, orange, and red colored) as fruit matured. In general, storage at $13{ }^{\circ} \mathrm{C}$ resulted in coloring of earlyharvested fruit, similar to the color of late-harvested fruit upon harvest. Hence, $13{ }^{\circ} \mathrm{C}$ storage appears to be the proper temperature for attaining optimum color of these dudaim fruit.

\section{Firmness}

At the beginning of storage, firmness of fruit harvested at 21 DAA (13.17-13.50 N) was significantly $(P<0.05)$ greater than that of late-harvested fruit (11.30-11.33 N) (Table 1). Early-harvested fruit at $13{ }^{\circ} \mathrm{C}$ underwent a gradual loss of firmness during storage, contrary to the fruit stored at $5{ }^{\circ} \mathrm{C}$, for which there were no significant changes. In late-harvested 'Zangi-Abad' fruit, there was a decrease in firmness during storage, with the magnitude of decrease greater at $13{ }^{\circ} \mathrm{C}$. The firmness of late-harvested 'Kermanshah' fruit at both storage temperatures did not have significant fluctuations during storage. In general, melon fruit harvested at 21 DAA were firmer than those harvested at 28 DAA, both immediately after harvest and at the end of storage, as was the case with 'Galia' melons (C. melo Group Cantalupensis) reported previously (Fallik et al., 2005). Several authors (Gil et al., 2006; Luna-Guzmán and 


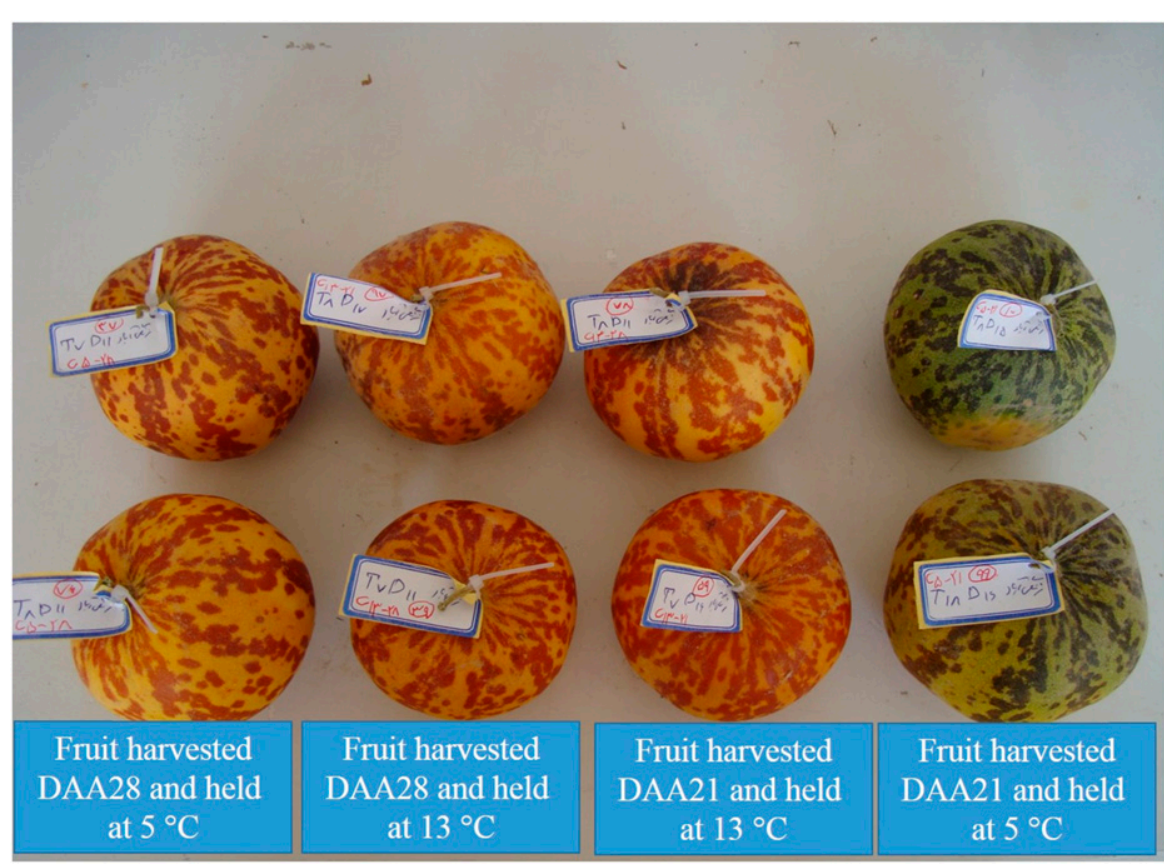

Fig. 3. 'Zangi-Abad' dudaim melon fruit harvested at 21 and $28 \mathrm{~d}$ after anthesis (DAA), after 3 weeks storage at 5 and $13{ }^{\circ} \mathrm{C}\left(41.0\right.$ and $\left.55.4{ }^{\circ} \mathrm{F}\right)$.
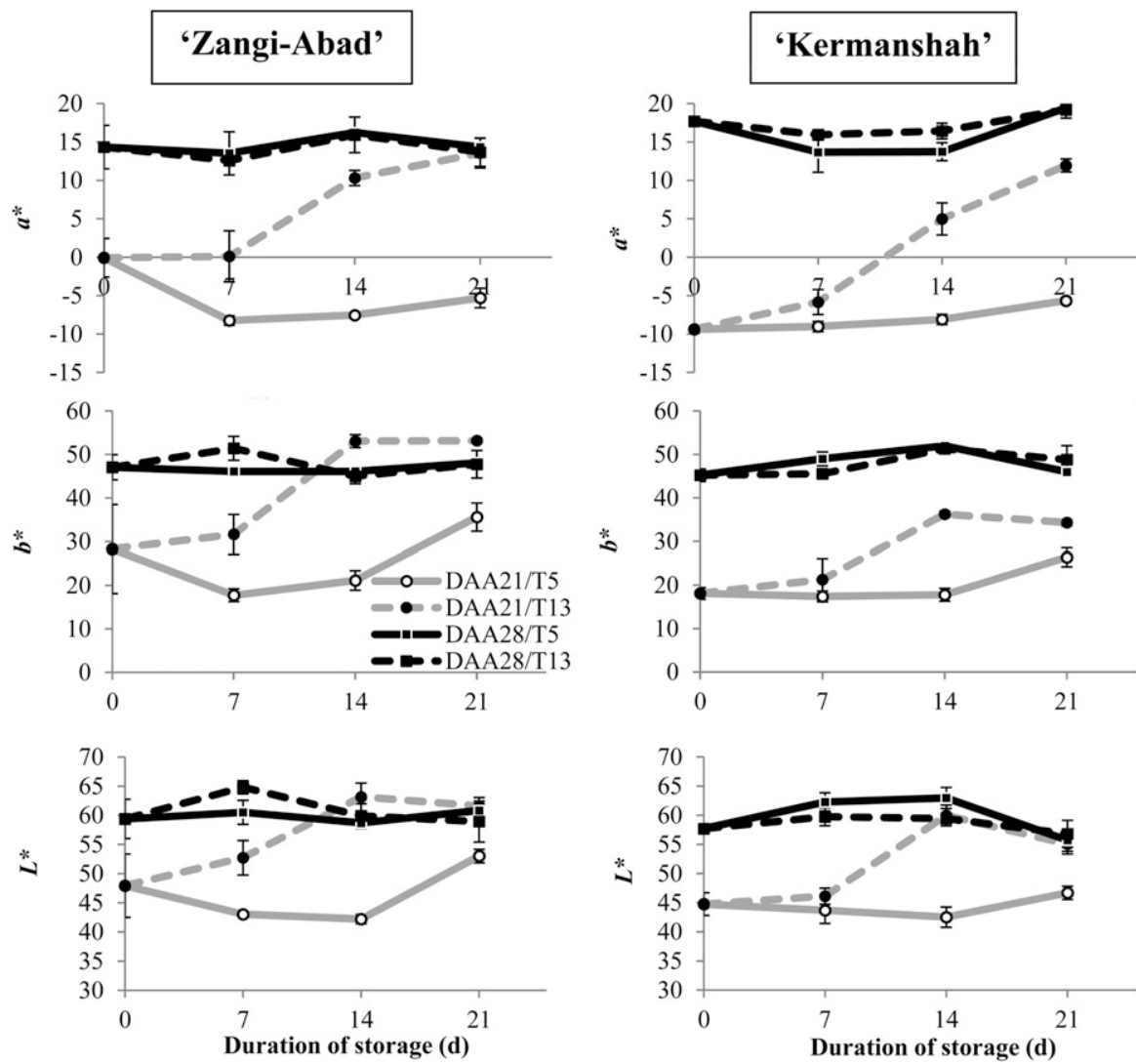

Fig. 4. Changes in $a^{*}$ (green-red tones), $b^{*}$ (blue-yellow tones), and $L^{*}$ (lightness) of early-harvested [21 d after anthesis (DAA)] and late-harvested (28 DAA) fruit of two dudaim melon cultivars (Zangi-Abad and Kermanshah) held at 5 and $13{ }^{\circ} \mathrm{C}$ $\left(41.0\right.$ and $55.4{ }^{\circ} \mathrm{F}$ ) for $21 \mathrm{~d}$. Vertical bars represent SE.

Barrett, 2000) have reported a loss of firmness during storage and ripening of melon fruit. In general, 21-DAA fruit harvested at 21 DAA was statistically greater compared to melons harvested at 28 DAA stored at 5 or $13{ }^{\circ} \mathrm{C}($ Table $\mathrm{l})$.

\section{TA, TSS, and weight loss}

During storage of early-harvested 'Zangi-Abad' and 'Kermanshah' fruit, there was often a gradual increase in TA level, followed by a gradual decrease until the end of the storage period at $13{ }^{\circ} \mathrm{C}$, when they ultimately attained a similar TA level to fruit harvested at 28 DAA (Table 1). The initial gradual increase is the result of the synthesis of organic acids, such as citric and malic acids (Davies and Hobson, 1981), and the subsequent decrease may be related to greater respiration and ripening rates, wherein organic acids could be used either as a substrate in respiration or in conversion to sugars (Hatami et al., 2013; Shahidul Islam et al., 1996).

In general, at harvest and during storage, the TSS content of fruit harvested at $28 \mathrm{DAA}$ was greater than that of early-harvested fruit. During the first week of storage, the TSS content of early-harvested fruit decreased, but then it started to increase slightly (Table 1 ). In the anthesistagged cantaloupe, the TSS content changes depended on the stage of ripeness at harvest (Beaulieu and Lea, 2007). Storage of harvested fruit at high temperatures hastens not only ripening but also the respiratory loss of stored carbohydrates (Saltveit, 2005).

The least weight loss occurred in fruit harvested at $28 \mathrm{DAA}$ at $5{ }^{\circ} \mathrm{C}$; the greatest weight loss was related to early-harvested fruit at $5{ }^{\circ} \mathrm{C}$ (Fig. 5 ). Storage of 21-DAA fruit at $5{ }^{\circ} \mathrm{C}$ resulted in greater water loss than storage at $13{ }^{\circ} \mathrm{C}$, but for 28 -DAA fruit, the reverse was true for both cultivars. Thus, DAA had a great effect on water loss at the two temperatures. Greater weight loss observed in early-harvested fruit may be related to a poorly developed epidermis and waxy cuticle compared with riper fruit (Saltveit, 2005), and the greater weight loss observed at $5{ }^{\circ} \mathrm{C}$ is likely related to CI symptoms. Percentage weight loss increased significantly $(P<0.05)$ in most treatments during storage. Cong et al. (2007) also reported weight loss of Hami melons resulting from transpiration during storage. fruit held at $5{ }^{\circ} \mathrm{C}$ did not soften as much as those held at $13^{\circ} \mathrm{C}$, and also the final firmness of 'Zangi-Abad' 
Table 1. Mean values for four fruit quality parameters of two dudaim melon cultivars (Zangi-Abad and Kermanshah) harvested at 21 and $28 \mathrm{~d}$ after anthesis (DAA) and stored at 5 and $13{ }^{\circ} \mathrm{C}\left(41.0\right.$ and $\left.55.4{ }^{\circ} \mathrm{F}\right)$ for up to $21 \mathrm{~d}$.

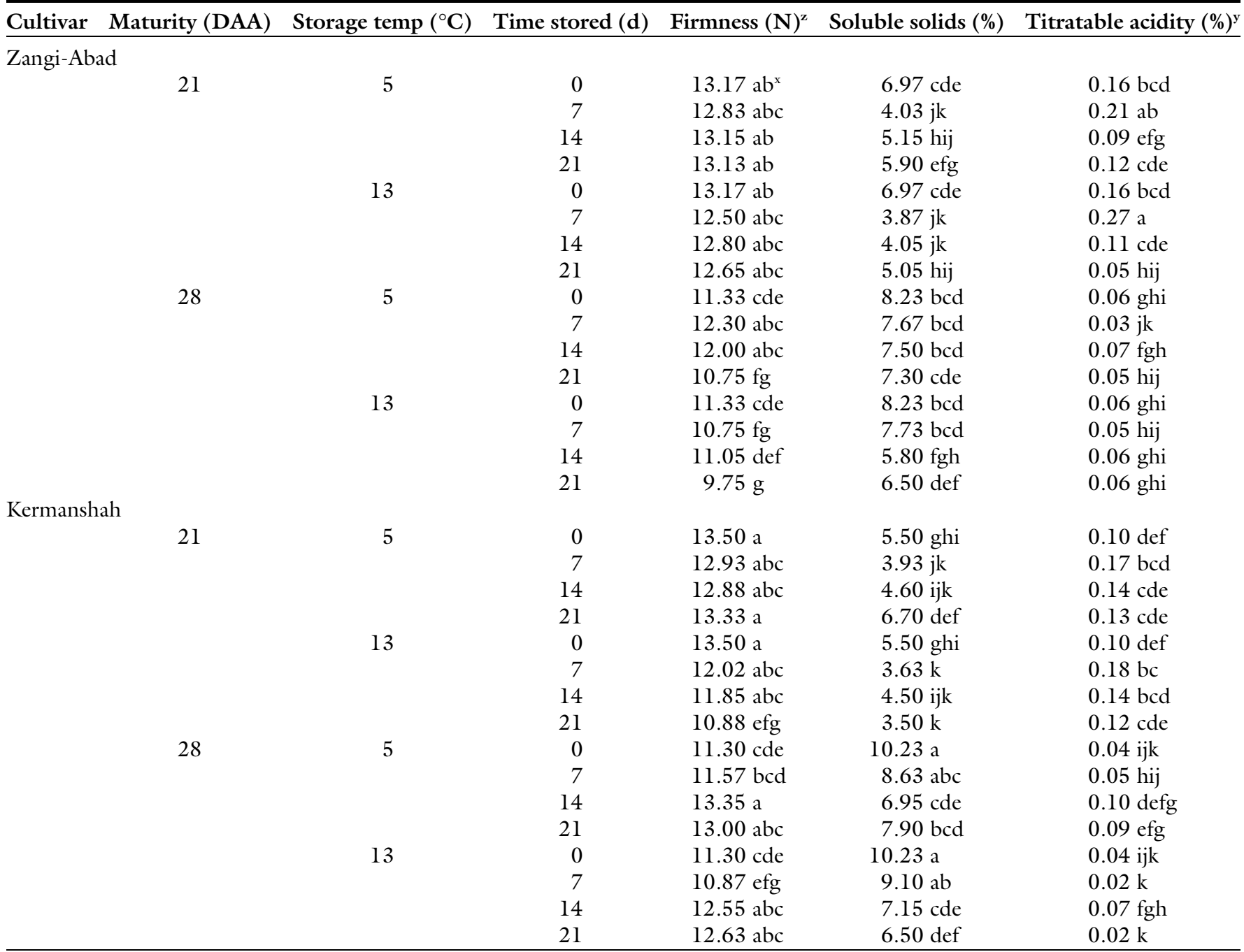

${ }^{\mathrm{z}} \mathrm{l} \mathrm{N}=0.2248 \mathrm{lbf}$.

y Expressed as percent citric acid.

${ }^{x}$ Means with different letter, within columns, are significantly different from each other by Duncan's new multiple range test at $P<0.05$.
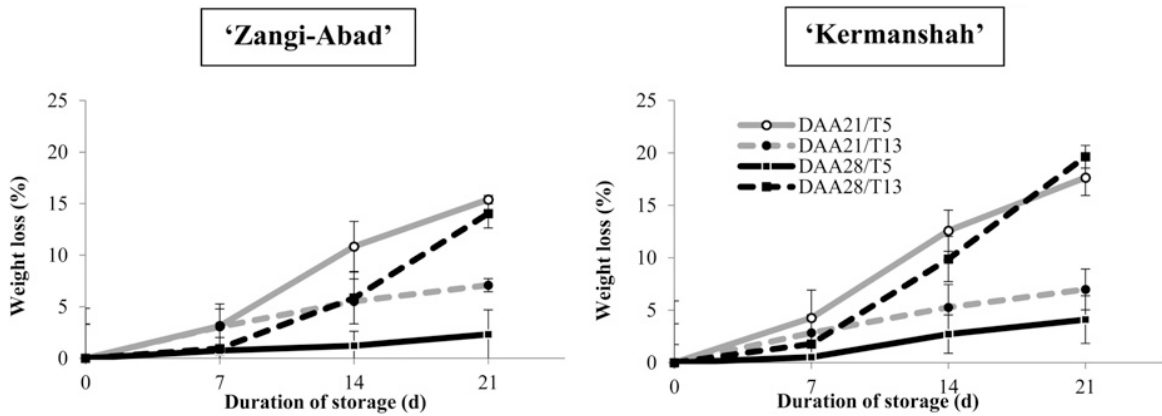

Fig. 5. Changes in weight loss of early-harvested [21 d after anthesis (DAA)] and late-harvested (28 DAA) fruit of two cultivars (Zangi-Abad and Kermanshah) of dudaim melon held at 5 and $13{ }^{\circ} \mathrm{C}\left(41.0\right.$ and $\left.55.4{ }^{\circ} \mathrm{F}\right)$ for $21 \mathrm{~d}$. Vertical bars represent SE.

\section{CI}

Symptoms of CI were significantly greater $(P<0.05)$ in earlyharvested fruit stored at $5{ }^{\circ} \mathrm{C}$ than in those stored at $13^{\circ} \mathrm{C}$ (Fig. 6). There were no significant differences between early-harvested 'Zangi-Abad' and 'Kermanshah' fruit stored at $5^{\circ} \mathrm{C}$.
A similar pattern was also observed in late-harvested 'Zangi-Abad' and 'Kermanshah' fruit at $5{ }^{\circ} \mathrm{C}$. Accelerated physiologic breakdown and increased incidence of pathologic decay occurs in chilling-sensitive melon fruit stored at a chilling temperature: typically less than $12{ }^{\circ} \mathrm{C}$ (Beaulieu and Gorny, 2016). Fruit harvested at $28 \mathrm{DAA}$ and stored at $5{ }^{\circ} \mathrm{C}$ showed significantly greater resistance to $\mathrm{CI}$ than fruit harvested at 21 DAA. Maturity is an important determinant of susceptibility to CI and it has been reported that ripening reduces chilling sensitivity for melon as well as for other fruit of tropical and subtropical origin (Whitaker, 1994). Ripe fruit are, almost by definition, more chilling resistant than green fruit and can be stored at lower, near-chilling temperatures (Saltveit, 2005). 


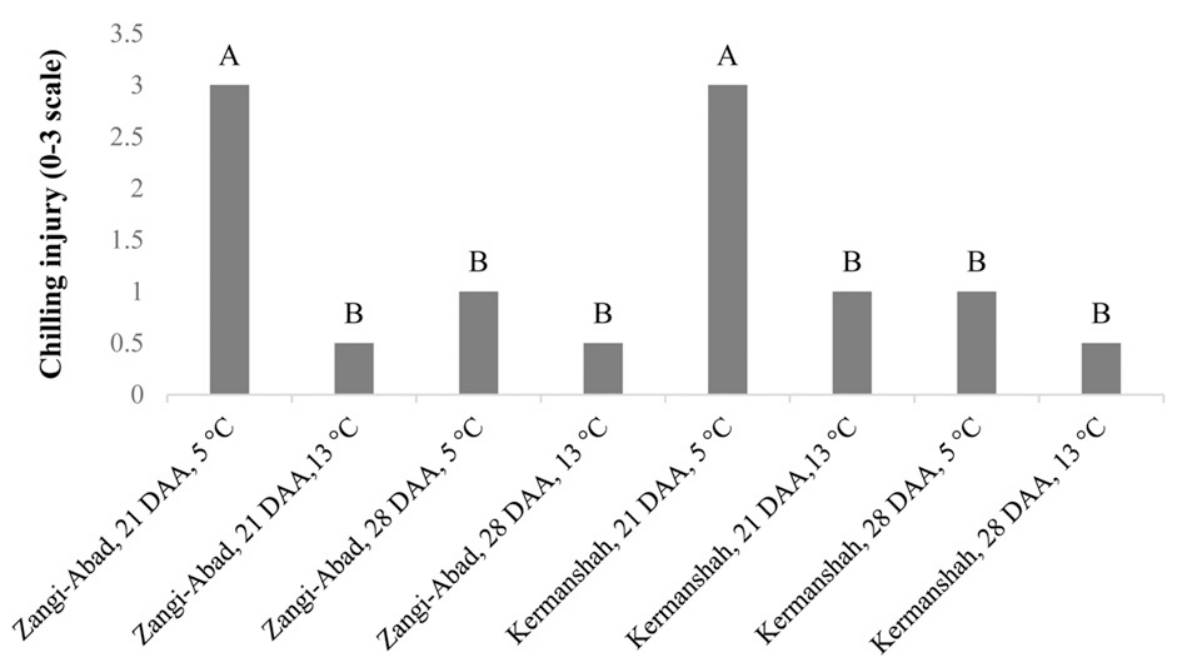

Fig. 6. Chilling injury of two dudaim melon cultivars harvested either 21 or 28 $\mathrm{d}$ after anthesis (DAA) and stored for 3 weeks at 5 or $13{ }^{\circ} \mathrm{C}\left(41.0\right.$ or $\left.55.4{ }^{\circ} \mathrm{F}\right)$. Injury was rated as follows, $0=$ no injury (no signs), $1=$ slight injury $(<20 \%$ of surface area), $2=$ moderate injury $(20 \%$ to $50 \%$ of surface area $)$, and $3=$ severe injury $(>50 \%$ of surface area). Values with a different letter are significantly different from each other by Duncan's new multiple range test at $P<0.05$.
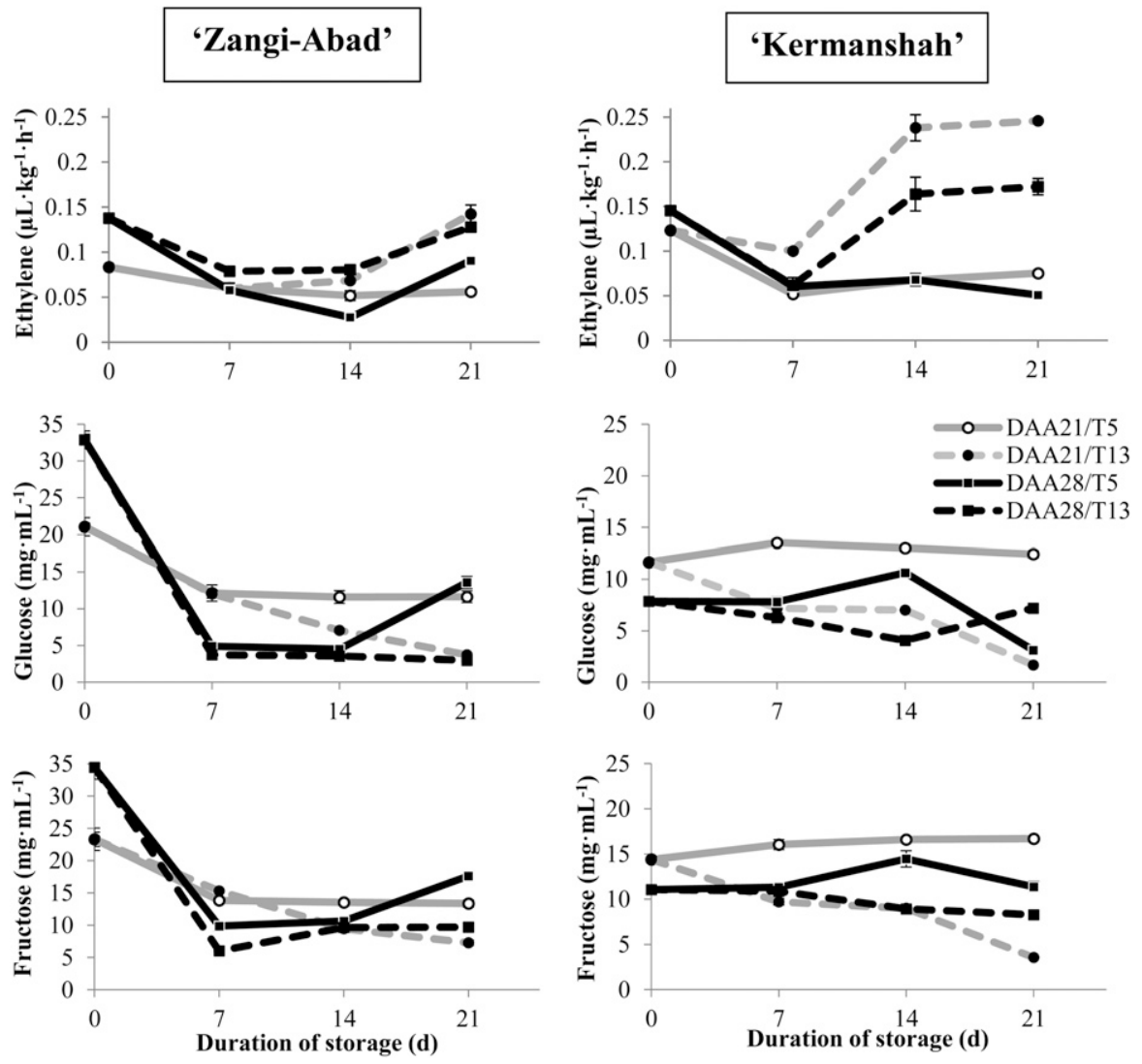

Fig. 7. Changes in ethylene, glucose, and fructose contents of early-harvested [21 $\mathrm{d}$ after anthesis (DAA)] and late-harvested (28 DAA) fruit of two dudaim melon cultivars (Zangi-Abad and Kermanshah) held at 5 and $13{ }^{\circ} \mathrm{C}\left(41.0\right.$ and $\left.55.4{ }^{\circ} \mathrm{F}\right)$ for $21 \mathrm{~d}$. Vertical bars represent SE. $1 \mu \mathrm{L} \cdot \mathrm{kg}^{-1}=1 \mathrm{ppm} ; 1 \mathrm{mg} \cdot \mathrm{mL}^{-1}=1000 \mathrm{ppm}$.

Although climacteric ripening seems to predispose the fruit to suffer more severe CI, this can be a collateral effect, as Fernandez-Trujillo et al.
(2008) did not establish conclusively a high correlation between the climacteric genes and CI. Overall, the greater the climacteric behavior, the greater the total loss of fruit quality and skin scald after storage, and the lower the fruit weight at harvest. However, exceptions were found to a positive correlation between climacteric pattern and upsurge in ethylene production, and decay disorders (Fernandez-Trujillo et al., 2008). Chilling sensitivity in melons can cause depressed and/or delayed ethylene production and increased susceptibility to rot. Ethylene production was depressed in both cultivars at $5{ }^{\circ} \mathrm{C}$ (Fig. 7). The CI may have been the result of reduced ethylene production per se or a result of the low storage temperature.

\section{Ethylene production}

Initial fruit ethylene levels in the two cultivars were greater in fruit harvested at 28 DAA than in fruit harvested at 21 DAA (Fig. 7). Ethylene production reached 0.14 and $0.25 \mu \mathrm{L} \cdot \mathrm{kg}^{-1} \cdot \mathrm{h}^{-1}$ in early-harvested 'Zangi-Abad' and 'Kermanshah' fruit stored at $13{ }^{\circ} \mathrm{C}$, respectively. Ethylene production was significantly greater in fruit stored at $13{ }^{\circ} \mathrm{C}$ than in fruit stored at $5^{\circ} \mathrm{C}(P<0.05)$, and production of ethylene at $5^{\circ} \mathrm{C}$ varied slightly during storage (Fig. 7). In 'Kermanshah', production decreased slightly during storage at $5{ }^{\circ} \mathrm{C}$, whereas at $13{ }^{\circ} \mathrm{C}$ there was an initial decrease followed by an increase in production through the end of storage.

Based on the ethylene and chilling data of 'Zangi-Abad', our results were inconclusive, because this cultivar may or may not be climacteric. For example, data collection could be confounded by insufficient harvest times (e.g., fruit were not physiologically mature) or insufficient time in storage, because the climacteric process could have begun at $21 \mathrm{~d}$ of storage, especially at $13{ }^{\circ} \mathrm{C}$. More DAA data points (e.g., $35 \mathrm{DAA}$ ) and longer postharvest storage could elucidate whether 'Zangi-Abad' is indeed climacteric. Meanwhile, perhaps the lower temperature did not allow enough time for recovery and/or a true display of ethylene production. Chilling injury in 'Zangi-Abad' may have exacerbated the poor results in ethylene compared with 'Kermanshah'. Alternatively, if 'Zangi-Abad' is indeed climacteric, ethylene might have already peaked, and day 0 values were then declining. This appears to 

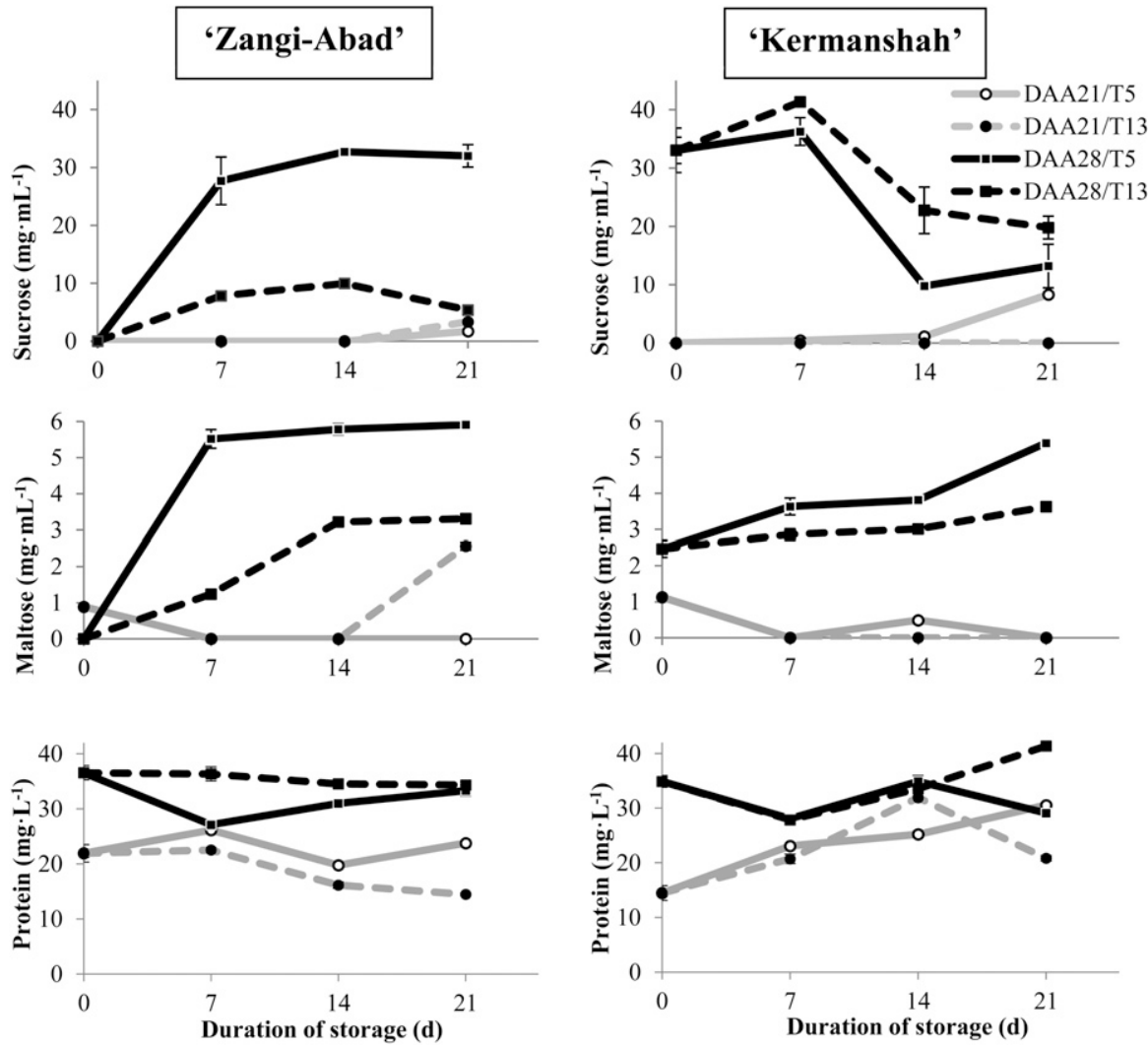

Fig. 8. Changes in sucrose, maltose, and protein contents of early-harvested [ 21 $\mathrm{d}$ after anthesis (DAA)] and late-harvested (28 DAA) fruit of two dudaim melon cultivars (Zangi-Abad and Kermanshah) held at 5 and $13{ }^{\circ} \mathrm{C}\left(41.0\right.$ and $\left.55.4{ }^{\circ} \mathrm{F}\right)$ for $21 \mathrm{~d}$. Vertical bars represent SE. $1 \mathrm{mg} \cdot \mathrm{mL}^{-1}=1000 \mathrm{ppm}$.

be supported by the color changes indicated pictorially. Subsequently, there was a general and slight overall senescent-induced increase in ethylene levels during storage.

\section{Sugar content}

GLUCOSE AND FRUCTOSE. The glucose and fructose contents of late-harvested 'Zangi-Abad' fruit on day 0 were significantly $(P<0.05)$ greater than those of early-harvested fruit (Fig. 7). In early-harvested 'Zangi-Abad' fruit at both temperature conditions, the amount of glucose and fructose generally declined during the storage period, and the reduction was augmented at $13{ }^{\circ} \mathrm{C}$. The reduction in glucose and fructose observed at $13{ }^{\circ} \mathrm{C}$ could be related to its conversion to disaccharide sugars (sucrose and maltose) at such a proper temperature for ripening. Glucose and fructose are used for sucrose formation and accumulation during ripening of muskmelon fruit (Hubbard et al., 1989; Ranwala et al., 1991). In late-harvested 'Zangi-Abad' fruit, there was a sharp decrease in the amount of these two sugars during the first week of storage and then they increased gradually until the end of storage.

The glucose and fructose contents of early-harvested 'Kermanshah' fruit on day 0 were significantly $(P<$ $0.01)$ greater than those of lateharvested fruit. Concerning 'Kermanshah' fruit harvested at 21 DAA and stored at $5{ }^{\circ} \mathrm{C}$, the concentrations of glucose and fructose did not fluctuate throughout the course of storage. Similarly, 'Kermanshah' fruit harvested at $28 \mathrm{DAA}$ and stored at $5^{\circ} \mathrm{C}$ displayed a slight increase in glucose and fructose levels until day 14. There was a gradual decrease, but this trend was almost reversed in fruit stored at $13{ }^{\circ} \mathrm{C}$. This is an appropriate temperature for the action of enzymes related to the ripening process so that glucose and fructose decreased and were likely incorporated into other sugars (Hubbard et al., 1989; Lester, 1998). The levels of glucose and fructose declined during the later stages of the development of oriental melon cultivars concomitant with the accumulation of sucrose (Zhang and Li, 2005).
Sucrose AND maltose. At the beginning of storage (day 0 ), the amount of sucrose and maltose in 'Zangi-Abad' fruit was very low (about $0-0.89 \mathrm{mg} \cdot \mathrm{mL}^{-1}$ ). In earlyharvested 'Zangi-Abad' fruit (21 DAA) at both temperature conditions (5 and $13{ }^{\circ} \mathrm{C}$ ), there was a slight increase during the first and second weeks (Fig. 8). However, during the last week of storage at $13{ }^{\circ} \mathrm{C}$, maltose exhibited a moderate increase. Sugar changes of late-harvested 'ZangiAbad' fruit (28 DAA) were completely different as the amount of the disaccharide sugar sucrose started from lower levels but finally reached significantly greater levels $(5.38$ and $32 \mathrm{mg} \cdot \mathrm{mL}^{-1}$ at 13 and $5^{\circ} \mathrm{C}$, respectively), especially at $5^{\circ} \mathrm{C}$ (Fig. 8).

In 'Kermanshah', the initial sucrose and maltose levels (day 0) of fruit harvested at 28 DAA were significantly greater than those of fruit harvested earlier. In early-harvested 'Kermanshah' fruit stored at $13{ }^{\circ} \mathrm{C}$, there was no disaccharide increase throughout the storage period, and the amounts of sucrose and maltose were low. In 'Kermanshah' fruit harvested later (28 DAA), the maltose content showed a markedly ascending trend, particularly at $5{ }^{\circ} \mathrm{C}$, whereas the trend for sucrose was the opposite, especially at $5{ }^{\circ} \mathrm{C}$. In general, greater amounts of maltose were observed in late-harvested fruit than in early-harvested fruit during storage.

There was almost no sucrose accumulation during the early stages of maturity in 'Zangi-Abad' fruit, and it has been well established that sucrose accumulates massively during the final stages of maturation and is the dominant sugar in most climacteric muskmelons (Beaulieu and Lea, 2007). Our results also indicate that the overall scheme of sugar variation in most treatments included increasing sucrose and maltose with advancing maturity. Monosaccharide sugars were consumed and disaccharide sugars were produced through enzymatic action (Hubbard et al., 1989) throughout storage, especially at $13{ }^{\circ} \mathrm{C}$, resulting in the increase in fruit sweetness.

\section{Protein content}

Late-harvested fruit (28 DAA) contained significantly greater total protein at the beginning of storage (day 0 ) than fruit harvested at 21 
DAA (Fig. 8). This difference persisted at most times during storage. In late-harvested 'Zangi-Abad' fruit, there was no significant protein increase at most times. In contrast, the protein content of early-harvested 'Zangi-Abad' fruit at $13{ }^{\circ} \mathrm{C}$ decreased at each time point during the 21$\mathrm{d}$ storage period. Perhaps 'ZangiAbad' was not even physiologically mature and/or not enough storage time had elapsed to see proper climacteric results. In early-harvested 'Kermanshah' fruit, protein content increased with the advance in storage time, except for the final week at $13{ }^{\circ} \mathrm{C}$, when it was the same as the first time point. In late-harvested 'Kermanshah' fruit, protein content fluctuated at $5{ }^{\circ} \mathrm{C}$ but increased at $13{ }^{\circ} \mathrm{C}$. At the end of storage (day 21), the greatest and least amounts of protein in both cultivars were related to late vs. early harvesting at $13{ }^{\circ} \mathrm{C}$, respectively. These results can be related to the supposition that early-harvested fruit (21 DAA) continued protein degradation through the ripening process. According to their presumed climacteric nature and their requirement for the use of substrates (such as carbohydrates and proteins) to complete the ripening process, the early-harvested fruit apparently catabolized more protein than the late-harvested fruit (28 DAA) (Ezura and Owino, 2008).

\section{Conclusion}

To the best of our knowledge, this study is the first attempt to evaluate the postharvest behavior of dudaim melon at two distinct maturity stages. In summary, our previous dudaim article (Hatami et al., 2016) and results herein indicate that the two evaluated dudaim cultivars have similar postharvest behaviors with respect to most assayed parameters at both 21- and 28-DAA harvests, but not when stored at $5{ }^{\circ} \mathrm{C}$. 'Kermanshah' dudaim fruit displayed climacteric behavior based on the parameters measured. Storage at $5{ }^{\circ} \mathrm{C}$ seemed to create some maturity-related "delays" regarding typical and normal ripening. For example, 'Zangi-Abad' held at $5{ }^{\circ} \mathrm{C}$ did not ripen fully (incomplete ethylene climacteric). Yet, this apparent chilling sensitivity could be confounded by insufficient DAA being assessed (i.e., if $35 \mathrm{DAA}$ was required in 'Zangi-Abad'). Storage at $13^{\circ} \mathrm{C}$ resulted in coloring of early-harvested fruit, with color development relatively similar to late-harvested fruit (28 DAA). Storage at $5{ }^{\circ} \mathrm{C}$ suppressed ethylene production in 'Kermanshah' in both 21 - and 28-DAA harvested fruit, whereas fruit held at $13{ }^{\circ} \mathrm{C}$ had greater ethylene production rates. Of the two test temperatures, $13{ }^{\circ} \mathrm{C}$ was a more appropriate temperature for storing dudaim fruit at different maturity stages. Further study could determine the per-cultivar-dependent optimum harvest windows regarding DAA.

\section{Literature cited}

Aubert, C. and M. Pitrat. 2006. Volatile compounds in the skin and pulp of queen anne's pocket melon. J. Agr. Food Chem. 54:8177-8182.

Beaulieu, J.C. 2006. Volatile changes in cantaloupe during growth, maturation and in stored fresh-cuts prepared from fruit harvested at various maturities. J. Amer. Soc. Hort. Sci. 131:127-139.

Beaulieu, J.C. and J.C. Gorny. 2016. Fresh-cut fruit, p. 604-623. In: K.C. Gross, C.Y. Wang, and M. Saltveit. The commercial storage of fruit, vegetables, and florist and nursery stocks. U.S. Dept. Agr., Agr. Res. Serv., Agr. Hdbk. 66.

Beaulieu, J.C. and V.A. Lancaster. 2007. Correlating volatile compounds, sensory attributes, and quality parameters in stored fresh-cut cantaloupe. J. Agr. Food Chem. 55:9503-9513.

Beaulieu, J.C. and J.M. Lea. 2007. Quality changes in cantaloupe during growth, maturation, and in stored freshcut cubes prepared from fruit harvested at various maturities. J. Amer. Soc. Hort. Sci. 132:720-728.

Bradford, M.M. 1976. A rapid and sensitive for the quantitation of microgram quantities of protein utilizing the principle of protein-dye binding. Anal. Biochem. 72:248-254.

Cai, X., H. Wang, and G. Pang. 2015. Flux control analysis of a lactate and sucrose metabolic network at different storage temperatures for Hami melon (Cucumis melo var. saccharinus). Scientia Hort. 181:4-12.

Cong, F., Y. Zhang, and W. Dong. 2007. Use of surface coatings with natamycin to improve the storability of Hami melon at ambient temperature. Postharvest Biol. Technol. 46:71-75.

Davies, J.N. and G.E. Hobson. 1981. The constituents of tomato fruit: The influence of environment, nutrition and genotype. Crit. Rev. Food Sci. Nutr. 15:205-279.
Ezura, H. and W.O. Owino. 2008. Melon, an alternative model plant for elucidating fruit ripening. Plant Sci. 175:121-129.

Fallik, E., Y. Shalom, S. Alkalai-Tuvia, O. Larkov, E. Brandesis, and U. Ravid. 2005. External, internal and sensory traits in Galia-type melon treated with different waxes. Postharvest Biol. Technol. 36:6975 .

Fernandez-Trujillo, J.P., J.M. ObandoUlloa, J.A. Martinez, E. Moreno, J. García-Mas, and A.J. Monforte. 2008. Climacteric and non-climacteric behavior in melon fruit: 2. Linking climacteric pattern and main postharvest disorders and decay in a set of near-isogenic lines. Postharvest Biol. Technol. 50:125-134.

Flores, F., M. Ben Amor, B. Jones, J.C. Pech, M. Bouzayen, A. Latché, and F. Romojaro. 2001. The use of ethylenesuppressed lines to assess differential sensitivity to ethylene of the various ripening pathways in cantaloupe melons. Physiol. Plant. 113:128-133.

Food and Agriculture Organization of the United Nations. 2016. Food and agricultural commodities production. 8 Apr. 2018. <http://www.fao.org/faostat/ en/\#data/QC $>$.

Gil, M.I., E. Aguayo, and A.A. Kader. 2006. Quality changes and nutrient retention in fresh-cut versus whole fruit during storage. J. Agr. Food Chem. 54:4284-4296.

Hatami, M., S. Kalantari, and M. Delshad. 2013. Responses of different maturity stages of tomato fruit to different storage conditions. Acta Hort. 1012:857-864.

Hatami, M., S. Kalantari, and F. Soltani. 2016. Different ripening indices and quality attributes of different groups of Cucumis melo. Intl. J. Hort. Sci. Technol. 3:69-76.

Hubbard, N.L., S.C. Huber, and D.M. Pharr. 1989. Sucrose phosphate synthase and acid invertase as determinants of sucrose concentration in developing muskmelon (Cucumis melo L.) fruit. Plant Physiol. 91:1527-1534.

Islamic Republic News Agency. 2014. Islamic Republic News Agency database. 8 Apr. 2018. <http://www.irna.ir/fa/ NewsPrint.aspx? $\mathrm{ID}=81254674>$.

Lester, G.E. 1998. Physicochemical characterization of hybrid honeydew muskmelon fruit (Cucumis melo L. var. inodorus Naud.) following maturation, abscission and postharvest storage. J. Amer. Soc. Hort. Sci. 123:126-129.

Lu, J., M.T. Charles, C. Vigneault, B. Goyette, and G.S.V. Raghavan. 2010. 
Effect of heat treatment uniformity on tomato ripening and chilling injury. Postharvest Biol. Technol. 56:155-162.

Luna-Guzmán, I. and D.M. Barrett. 2000. Comparison of calcium chloride and calcium lactate effectiveness in maintaining shelf stability and quality of fresh-cut cantaloupes. Postharvest Biol. Technol. 19:61-72.

Muir, J.G., R. Rose, O. Rosella, K. Liels, J.S. Barrett, S.J. Shepherd, and P.R. Gibson. 2009. Measurement of short-chain carbohydrates in common Australian vegetables and fruits by high-performance liquid chromatography (HPLC). J. Agr. Food Chem. 57:554-565.

Munger, H.M. and R.W. Robinson. 1991. Nomenclature of Cucumis melo L. Rep. Cucurbit Genet. Coop. 14:43-44.

Nunez-Palenius, H.G., M. Gomez-Lim, N. Ochoa-Alejo, R. Grumet, G. Lester, and D.J. Cantliffe. 2008. Melon fruit: Genetic diversity, physiology, and biotechnology features. Crit. Rev. Biotechnol. 28:13-55.

Paris, H.S., Z. Amar, and E. Lev. 2012. Medieval history of the duda'im melon (Cucumis melo, Cucurbitaceae). Econ. Bot. 66:276-284.

Pech, J.C., M. Bouzayen, and A. Latche. 2008. Climacteric fruit ripening: Ethylene dependent and independent regulation of ripening pathways in melon fruit. Plant Sci. 175:114-120.

Pitrat, M. 2016. Melon genetic resources: Phenotypic diversity and horticultural taxonomy, p. 25-60. In: R. Grumet, N. Katzir, and J. Garcia-Mas (eds.). Genetics and genomics of Cucurbitaceae. Springer Science Media, New York, NY.

Pratt, H.K. 1971. Melons, p. 207-232. In: A.C. Hulme (ed.). The biochemistry of fruit and their products. Academic Press, New York, NY.

Pratt, H.K., J.D. Goesschl, and F.W. Martin. 1977. Fruit growth and development, ripening and role of ethylene in the 'Honey Dew' muskmelon. J. Amer. Soc. Hort. Sci. 102:203-210.

Raghami, M., A.I. Lopez-Sese, M.R. Hasandokht, Z. Zamani, M.R. Fattahi Moghadam, and A. Kashi. 2013. Genetic diversity among melon accessions from Iran and their relationships with melon germplasm of diverse origins using microsatellite markers. Plant Syst. Evol. 300:139-151.

Ranwala, A.P., C. Suematsu, and H. Masuda. 1991. Acid and neutral invertases in the mesocarp of developing muskmelon (Cucumis melo L. cv. Prince) fruit. Plant Physiol. 96:881-886.

Saltveit, M.E. 2005. Postharvest biology and handling, p. 305-324. In: E. Heuvelink (ed.). Tomatoes. CAB Intl., Wallingford, UK.

Shahidul Islam, M., T. Matsui, and Y. Yoshida. 1996. Effect of carbon dioxide enrichment on physico-chemical and enzymatic changes in tomato fruit at various stages of maturity. Scientia Hort. 65:137149.

Shu, C.K., H.L. Chung, and B.M. Lawrence. 1995. Volatile components of pocket melon (Cucumis melo L. ssp dudaim Naud.). J. Essent. Oil Res. 7:179-181.

Silva, J.A., T.S. Da Costa, L. Lucchetta, L.J. Marini, M.R. Zanuzo, L. Nora, A.F.R. Nora, R.M. Twyman, and C.V. Rombaldi. 2004. Characterization of ripening behavior in transgenic melons expressing an antisense 1-aminocyclopropane-1-carboxylate (ACC) oxidase gene from apple. Postharvest Biol. Technol. 32:263-268.

Soltani, F., Y. Akashi, A. Kashi, Z. Zamani, Y. Mostofi, and K. Kato. 2010. Characterization of Iranian melon landraces of Cucumis melo L. Groups Flexuosus and Dudaim by analysis of morphological characters and random amplified polymorphic DNA. Breed. Sci. 60:34-45.

Whitaker, B.D. 1994. A reassessment of heat treatment as a means of reducing. Postharvest Biol. Technol. 4:75-83.

Zeinalipour, N., K. Haghbeen, I. Tavassolian, A.A. Karkhane, and J. Ghashghaie. 2017. Enhanced production of 3methylthiopropionic ethyl ester in native Iranian Cucumis melo L. group dudaim under regulated deficit irrigation. J. Funct. Foods 30:56-62.

Zhang, M.F. and Z.L. Li. 2005. A comparison of sugar-accumulating patterns and relative compositions in developing fruit of two oriental melon varieties as determined by HPLC. Food Chem. 90:785-790. 